\title{
Insulinoma-Associated Protein 2 Antibody Measurement
}

National Cancer Institute

\section{Source}

National Cancer Institute. Insulinoma-Associated Protein 2 Antibody Measurement. NCI

Thesaurus. Code C119284.

The determination of the amount of insulinoma-associated protein 2 antibody in a biological specimen. 